\title{
HUBUNGAN PENGETAHUAN GIZI DAN KEBIASAAN MAKAN DENGAN BERAT BADAN SANTRIWATI DI PONDOK PESANTREN AMANATUL UMMAH SURABAYA
}

\author{
Dewi Putri Kurniawati ${ }^{1}$, Wesiana Heris Santy ${ }^{1}$, Pratiwi Hariyani Putri ${ }^{2}$ \\ ${ }^{1}$ Program Studi S1 Keperawatan, Fakultas Keperawatan dan Kebidanan \\ ${ }^{2}$ Program Studi S1 Gizi, Fakultas Kesehatan \\ Universitas Nahdlatul Ulama Surabaya \\ Email: dewi.putri205@gmail.com
}

\begin{abstract}
The nutrition problems that often occur in adolescence are multiple nutritional problems that is overweight and thin. It's happen because imbalace between energy consumption and expulsion energy in the body metabolism. The prevalence of overweight and thin teenagers aged $16-18$ are rising each year. The purpose of this research is to know the relation of nutrition knowledge and eating habits with weight of santriwati in boarding school Amanatul Ummah Surabaya. The design of this research is the cross sectional. The sample of research is 45 respondents, taken using a proportional random sampling. The instrument using a questionnaire, data analysis using spearman rank test with significance level 0.05. The research shows that almost half of the repondent having overweight (31.1\%) and a small part has skinny (11.1\%). The results of the test of rank spearman shows there is unrelation between nutrition knowledge with weight $(p=0,205)$ and there is relation between eating habits with weight $(p=0.000)$. It can be concluded that nutritional knowledge does not affect a person to choose nutritious foods and according to the need, but eating habits will effect for weight. Teenagers should apply of nutrition knowledge that they have so can change eating habits.
\end{abstract}

Keywords: Knowledge of Nutrition, Eating Habits, Weight

\begin{abstract}
ABSTRAK
Masalah gizi yang sering terjadi pada masa remaja adalah masalah gizi ganda yaitu gizi lebih (kelebihan berat badan) dan gizi kurang (kurus). Hal ini terjadi karena ketidakseimbangan antara konsumsi energi dan pengeluaran energi dalam metabolisme tubuh. Prevalensi kegemukan pada remaja umur 16 - 18 dan kurus mengalami kenaikan setiap tahunnya. Penelitian ini bertujuan untuk mengetahui hubungan pengetahuan gizi dan kebiasaan makan dengan berat badan santriwati di Pondok Pesantren Amanatul Ummah Surabaya. Desain penelitian ini adalah cross sectional. Sampel penelitian berjumlah 45 responden, diambil menggunakan proportional random sampling. Instrumen menggunakan kuisioner, analisa data menggunakan uji rank spearman dengan tingkat kemaknaan 0,05. Hasil penelitian menujukkan bahwa hampir setengah reponden memiliki berat badan berlebih $(31,1 \%)$ dan sebagian kecil memiliki berat badan kurus $(11,1 \%)$. Hasil uji rank spearman menunjukkan tidak ada hubungan yang bermakna $(\mathrm{p}=0,205)$ antara pengetahuan gizi dengan berat badan dan terdapat hubungan yang bermakna $(\mathrm{p}=0,000)$ antara kebiasaan makan dengan berat badan. Dapat disimpulkan pengetahuan gizi tidak mempengaruhi seseorang memilih
\end{abstract}


makanan yang bergizi dan sesuai dengan kebutuhan, namun kebiasaan makan akan berpengaruh terhadap berat badan. Remaja hendaknya menerapkan pengetahuan gizi yang dimiliki sehingga dapat mengubah kebiasaan makan.

Kata kunci: Pengetahuan Gizi, Kebiasaan Makan, Berat Badan

\section{PENDALUHUAN}

Gizi pada masa remaja penting untuk diperhatikan. Karena masa remaja merupakan masa "rawan gizi" yaitu kebutuhan akan gizi sangat tinggi. Hal ini dikarenakan pada masa remaja akan terjadi perubahan fisik, aspek sosial, maupun psikologis. Masalah gizi yang sering terjadi pada masa remaja adalah masalah gizi ganda yaitu gizi lebih (kelebihan berat badan) dan gizi kurang (kurus). ${ }^{1}$

Berdasarkan Riskesdas (2013) pada remaja umur 16-18 tahun, Prevalensi kegemukan pada tahun 2010 yaitu sebesar 1,4 persen, namun mengalami kenaikan pada tahun 2013 menjadi 7,3 persen $(5,7 \%$ gemuk dan obesitas 1,6 obesitas). Sedangkan prevalensi kurus pada tahun 2010 yaitu sebesar 8,9 persen $(1,8 \%$ sangat kurus dan $7,1 \%$ kurus) dan mengalami kenaikan pada tahun 2013 menjadi 9,4 persen (1,9\% sangat kurus dab 7,5\% kurus). ${ }^{2}$

Faktor yang dapat mempengaruhi berat badan adalah pola makan, faktor kesehatan, jenis kelamin, aktivitas fisik, faktor gen, faktor lingkungan, faktor psikososial, faktor perkembangan. ${ }^{3}$ Selain itu Pengetahuan gizi dan kebiasaan makan merupakan faktor tidak langsung yang dapat mempengaruhi berat badan. Pengetahuan gizi yang baik dapat mengubah kebiasaan makan remaja sehingga dapat mempengaruhi pola makan remaja dalam memilih makanan yang bergizi sesuai selera dan kebutuhan. Kebiasaan makan remaja yang suka mengkonsumsi cemilan, junk food, dan kurang mengkonsumsi serat dapat mengakibatkan masalah gizi kelebihan berat badan yang merupakan faktor resiko beberapa penyakit degeneratif. Khomsan (2010) menjelaskan kelebihan berat badan dapat menyebabkan penyakit hipertensi, jantung koroner, diabetes melitus dan penyakit pernapasan. ${ }^{1}$

Solusi dalam mengatasi masalah di atas adalah dengan meningkatkan pengetahuan remaja tentang gizi dan merubah kebiasaan remaja dalam memilih makanan yang baik bagi tubuh. Jika remaja yang memiliki pengetahuan gizi yang baik, maka dapat merubah kebiasaan makan remaja dalam memilih makanan yang bergizi dan sesuai kebutuhan sehingga pada akhirnya dapat membuat status gizi yang baik pada remaja. Selain itu, melihat dari penelitian sebelumnya yang berjudul "Studi Tentang Pengetahuan Gizi, Kebiasaan Makan, Aktivitas Fisik, Status Gizi Dan Body Image Remaja Putri Berstatus Gizi Normal Dan Gemuk/Obes Di SMA Budi Mulia Bogor", maka peneliti akan melakukan penelitian tentang hubungan 
pengetahuan gizi dan kebiasaan makan dengan berat badan santriwati Di Pondok Pesantren Amanatul Ummah Surabaya dengan menggunakan uji dan metode yang berbeda untuk mengetahui hubungan antar variabel.

\section{METODE PENELITIAN}

Penelitian ini merupakan studi epidemiologi dengan jenis penelitian analitik. Desain penelitian ini adalah cross sectional. Penelitian ini dilaksanakan di Pondok Pesantren Amanatul Ummah Surabaya, dengan jumlah responden sebesar 45 santriwati. Cara pengambilan sampel menggunakan teknik proportional random sampling. Untuk melihat hubungan antara variabel independen dan variable dependen dengan menggunakan analisis uji rank spearmen dengan nilai signifikan $\alpha 0,05$.

\section{HASIL DAN PEMBAHASAN}

\section{Pengetahuan Gizi Santriwati}

Tabel 1 Distribusi Pengetahuan Gizi Santriwati Pondok Pesantren Amanatul Ummah Surabaya

\begin{tabular}{lcc}
\hline Pengetahuan Gizi & $\begin{array}{c}\text { Frekuensi } \\
(\mathrm{n})\end{array}$ & $\begin{array}{c}\text { Persentase } \\
(\%)\end{array}$ \\
\hline Baik $(>80 \%)$ & 6 & 13,3 \\
Cukup $(60-80 \%)$ & 22 & 48,9 \\
Kurang $(<80 \%)$ & 17 & 37,8 \\
\hline Total & 45 & 100,0 \\
\hline
\end{tabular}

Berdasarkan hasil penelitian yang dilakukan, dari 45 santriwati didapatkan bahwa sebagian besar memiliki pengetahuan gizi cukup sebesar $48,9 \%$, namun masih terdapat pengetahuan gizi kurang sebesar 37,8\%. Penelitian yang dilakukan di dua Pesantren Modern (Sahid dan Ummul Quro Al-Islam) di Kabupaten Bogor juga menunjukkan santriwati di Pondok Pesantren Sahid yang memiliki pengetahuan gizi cukup sebesar $49 \%$ dan santriwati yang memiliki pengetahuan gizi kurang sebesar $24 \%$, sedangkan santriwati di Pondok Pesantren Ummul Quro Al-Islam yang memiliki pengetahuan gizi cukup sebesar $48 \%$ dan santriwati yang memiliki pengetahuan gizi kurang sebesar $30 \% .^{4}$

Hal ini menunjukkan bahwa rata-rata santriwati telah memiliki pengetahuan cukup, sehingga diharapkan dengan pengetahuan remaja yang cukup diharapkan reponden dapat memilih makanan yang bergizi dan sesuai kebutuhan. Dieny (2014) menyatakan pengetahuan remaja erat kaitanya dengan pendidikan. Pengetahuan gizi mempengaruhi seseorang dalam pemilihan makanan sehat dalam kehidupan sehari-hari. ${ }^{5}$

\section{Kebiasaan Makan Santriwati}

Tabel 2 Distribusi Kebiasaan Makan Santriwati Pondok Pesantren Amanatul Ummah Surabaya

\begin{tabular}{|c|c|c|}
\hline Kebiasaan Makan & $\begin{array}{l}\text { Frekuensi } \\
\text { (n) }\end{array}$ & $\begin{array}{c}\text { Persentase } \\
(\%)\end{array}$ \\
\hline $\begin{array}{l}\text { Berlebihan } \\
(\geq 120 \%)\end{array}$ & 14 & 31,1 \\
\hline Normal (90-119\%) & 25 & 55,6 \\
\hline $\begin{array}{l}\text { Defisit Ringan (80- } \\
89 \% \text { ) }\end{array}$ & 6 & 13,3 \\
\hline $\begin{array}{l}\text { Defisit } \\
(70-79 \%)\end{array}$ & 0 & 0 \\
\hline $\begin{array}{l}\text { Defisit } \\
(<70 \%)\end{array}$ & 0 & 0 \\
\hline Total & 45 & 100,0 \\
\hline
\end{tabular}


Berdasarkan hasil penelitian yang dilakukan, dari 45 santriwati didapatkan bahwa sebagian besar memiliki kebiasaan makan normal sebanyak 55,6\%, hal ini dikarenakan santriwati telah mengkonsumsi makanan dari sumber kabohidrat, protein, sayur dan buah. Hal ini dibuktikan dari hasil SQ-FFQ diperoleh hasil bahwa seluruhnya (100\%) santriwati mengkonsumsi beras giling sebagai makanan yang bersumber dari karbohidrat, hampir seluruhnya (91\%) santriwati mengkonsumsi sayur gubis, seluruhnya $(100 \%)$ santriwati mengkonsumsi tempe sebagai makanan yang bersumber dari protein, hampir setengah (40\%) santriwati mengkonsumsi buah alpukat.

Berdasarkan hasil penelitian didapatkan bahwa hampir setengahnya $(31,1 \%)$ memiliki kebiasaan makan berlebih. Adanya kebiasaan makan berlebih pada santriwati dikarenakan santri tidak hanya mengkonsumsi makanan yang disediakan oleh pondok pesantren, namun masih bisa mengkonsumsi makanan yang diperoleh dari kantin pondok pesantren seperti mie instan dan roti. Hal ini dibuktikan dari hasil SQ-FFQ diperoleh hasil bahwa seluruhnya (100\%) santriwati mengkonsumsi snack/ makanan ringan sebagai makanan yang bersimber dari makanan instan. Proverawati (2011) mengatakan kebiasaan makan merupakan faktor penting yang dapat mempengaruhi status gizi dan kesehatan seseorang khususnya remaja yang membutuhkan asupan gizi yang cukup dalam perkembangannya. ${ }^{3}$ Pada masa remaja kebiasaan makan telah terbentuk, remaja mempunyai pilihan sendiri terhadap makanan yang disenangi. Pada umumnya remaja lebih suka makan makanan yang kurang bergizi seperti goreng-gorengan, coklat, permen dan es. Sehingga makanan yang beraneka ragam tidak dikonsumsi. ${ }^{3}$

\section{Berat Badan Santriwati}

Tabel 3. Distribusi Berat Badan Santriwati Pondok Pesantren Amanatul Ummah Surabaya

\begin{tabular}{lcc}
\hline Berat Badan & $\begin{array}{c}\text { Frekuensi } \\
(\mathrm{n})\end{array}$ & $\begin{array}{c}\text { Persentase } \\
(\%)\end{array}$ \\
\hline Kelebihan (>1 SD) & 14 & 31,1 \\
Normal (-2 SD s/d 1 & 26 & 57,8 \\
SD) & 5 & 11,1 \\
Kurus (<-2 SD) & 45 & 100,0 \\
\hline Total & & \\
\hline
\end{tabular}

Berdasarkan hasil penelitian yang dilakukan, dari 45 santriwati didapatkan bahwa sebagian besar memiliki berat badan normal sebesar 57,8\%. Namun masih terdapat santri yang memiliki berat badan lebih dengan persentase sebesar $31,1 \%$ dan berat badan kurus sebesar $11,1 \%$. Persentase kelebihan berat badan dan berat badan kurus pada penelitian ini bila dibandingkan dengan data Riskesdas (2013), angka tersebut telah melebihi prevalensi nasional yaitu $9,4 \%$ untuk berat badan kurus dan 7,3\% untuk kelebihan berat badan. $^{2}$

Permasalahan berat badan pada remaja dapat menimbulkan beberapa dampak negatif pada kesehatan. Kegemukan merupakan salah satu faktor resiko dalam terjadinya berbagai 
penyakit degeneratif, Khomsan (2010) menjelaskan kelebihan berat badan dapat pernapasan. Sedangkan kekurangan gizi dapat menyebabkan penyakit hipertensi, jantung mengakibatkan gangguan pada proses koroner, diabetes melitus dan penyakit tubuh, struktur fungsi otak dan perilaku. ${ }^{1}$

\section{Hubungan Pengetahuan Gizi dengan Berat Badan}

Tabel 4 Hubungan Antara Pengetahuan Gizi dengan Berat Badan Santriwati Pondok Pesantren Amanatul Ummah Surabaya

\begin{tabular}{|c|c|c|c|c|c|c|c|c|c|}
\hline \multirow{3}{*}{ Pengetahuan gizi } & \multicolumn{6}{|c|}{ Berat badan responden } & \multicolumn{2}{|c|}{ Total } & \multirow[t]{2}{*}{$P$-Value } \\
\hline & \multicolumn{2}{|c|}{$\begin{array}{l}\text { Kelebihan } \\
(>1 \text { SD })\end{array}$} & \multicolumn{2}{|c|}{$\begin{array}{c}\text { Normal } \\
(-2 \mathrm{SD} s / \mathrm{d} 1 \mathrm{SD})\end{array}$} & \multicolumn{2}{|c|}{$\begin{array}{c}\text { Kurus } \\
(<-2 \text { SD) }\end{array}$} & & & \\
\hline & $\mathrm{n}$ & $\%$ & $\mathrm{n}$ & $\%$ & $\mathrm{n}$ & $\%$ & $\mathrm{n}$ & $\%$ & 0,205 \\
\hline Baik (>80\%) & 3 & 50,0 & 2 & 33,3 & 1 & 16,7 & 6 & 100 & \\
\hline Cukup (60-80\%) & 8 & 36,4 & 12 & 54,5 & 2 & 9,1 & 22 & 100 & \\
\hline Kurang $(<80 \%)$ & 3 & 17,6 & 12 & 70,6 & 2 & 11,8 & 17 & 100 & \\
\hline Total & 14 & 31,1 & 26 & 57,8 & 5 & 11,1 & 45 & 100 & \\
\hline
\end{tabular}

Pengetahuan gizi dapat diartikan sebagai pengetahuan tentang makanan dan zat gizi. Pengetahuan gizi mempengaruhi seseorang dalam pemilihan makanan sehat dalam kehidupan sehari-hari. Semakin tinggi pengetahuan gizi seseorang diharapkan semakin baik pula keadaan gizinya. ${ }^{5}$

Berdasarkan hasil penelitian diketahui bahwa dari 6 santriwati yang pengetahuan gizinya baik setengahnya (50\%) memiliki berat badan lebih. Berdasarkan hasil uji statistik dengan menggunakan rank spearman diperoleh nilai signifikansi sebesar 0,205. Hal ini menunjukkan tidak ada hubungan bermakna antara pengetahuan gizi dengan berat badan. Hasil penelitian ini relevan dengan penelitian Amelia (2008), yang menunjukkan tidak ada hubungan signifikan antara pengetahuan gizi dengan status gizi $(p=>0,05) .{ }^{6}$ Namun hasil penelitian ini bertolak belakang dengan penelitian yang dilakukan oleh Laenggeng (2015) yang menunjukkan terdapat hubungan yang sangat rendah antara pengetahuan gizi dengan status gizi siswa di SMP Negeri 1 Palu $(\mathrm{R}=0,131){ }^{7}$

Tidak adanya hubungan ini kemungkinan disebabkan adanya kurangnya kemampuan untuk menerapakan informasi yang didapat dalam kehidupan sehari-hari. Hal ini juga didukung karena kondisi lingkungan yang tidak mendukung responden memperoleh makanan yang bergizi, ditandai tidak tersedianya buah di kantin pondok pesatren.

Menurut Wawan (2011), faktor-faktor yang mempengaruhi pengetahuan ada dua yaitu faktor internal yang terdiri dari pendidikan, pekerjaan dan umur. Sedangkan yang kedua adalah faktor eksternal yang terdiri dari faktor lingkungan dan sosial budaya. ${ }^{8}$ Kecenderungan seseorang remaja untuk memiliki motivasi 
berperilaku kesehatan yang baik dipengaruhi oleh tingkat pengetahuan, sikap dan keterampilannya. ${ }^{9}$ Apabila penerimaan perilaku didasari oleh pengetahuan, kesadaran dan sikap yang positif maka perilaku tersebuat akan berlangsung lama (long lasting). ${ }^{10}$

\section{Hubungan Kebiasaan Makan dengan Berat Badan}

Tabel 5 Hubungan Antara Kebiasaan Makan dengan Berat Badan Santriwati Pondok Pesantren Amanatul Ummah Surabaya

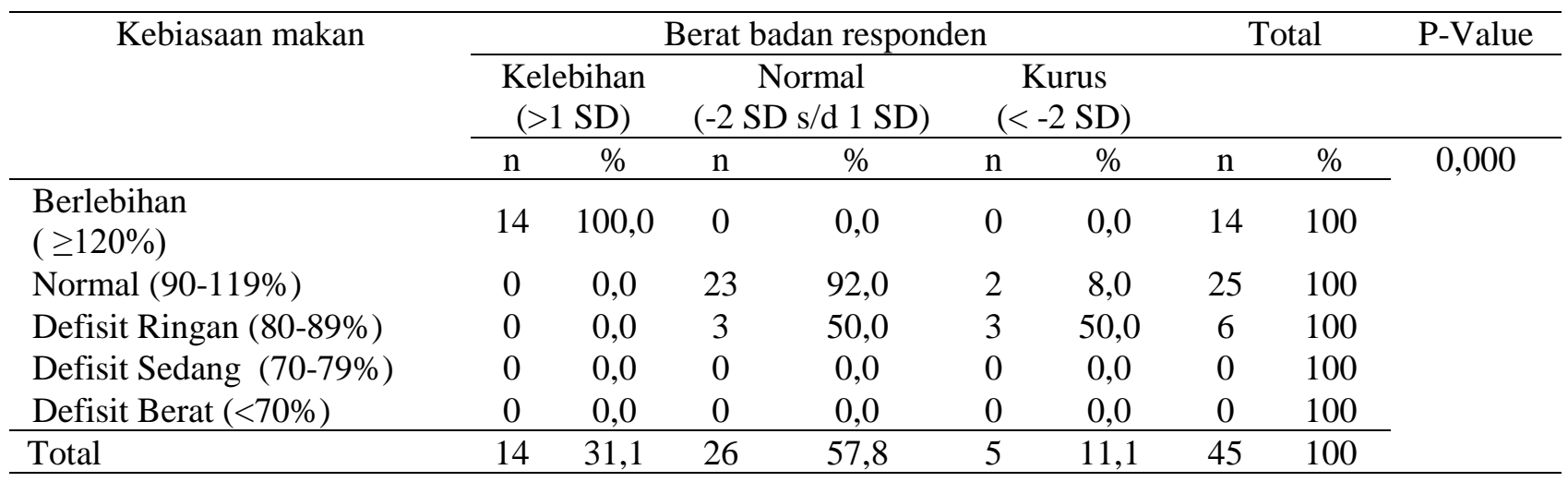

Kebiasaan makan merupakan respon kebiasaan atau perilaku yang berhubungan dengan konsumsi makanan meliputi jenis makanan, jumlah, dan waktu mengkonsumsi makanan. ${ }^{5}$ Berdasarkan hasil penelitian diketahui bahwa bahwa dari 14 santriwati yang kebiasaan makannya berlebih seluruhnya (100\%) memiliki berat badan berlebih, dari 25 santriwati yang kebiasaan makannya normal hampir seluruhnya (92\%) memiliki berat badan normal.

Berdasarkan hasil SQ-FFQ diperoleh hasil bahwa seluruhnya (100\%) santriwati mengkonsumsi snack/makanan ringan. Kebiasaan makan santriwati yang sering mengkonsumsi snack ini terjadi karena jarak antara makan siang dan makan malam adalah selama 8 jam sehingga santriwati banyak yang mengkonsumsi snack, mie instan ataupun gorengan selama waktu tersebut. Berdasarkan hasil uji statistik dengan menggunakan rank spearman diperoleh nilai signifikansi sebesar 0,000. Hal ini menunjukkan ada hubungan bermakna antara kebiasaan makan dengan berat badan.

Hasil penelitian ini sejalan dengan penelitian Zuhdy (2015), yang menunjukkan ada hubungan signifikan antara pola makan dengan status gizi $(\mathrm{p}=<0,05) .{ }^{11}$ Hasil penelitian Siregar (2013) juga menunjukkan ada hubungan pola makan dengan kejadian overweight $(p=0,00) .{ }^{12}$ Kebiasaan makan biasanya akan berubah saat masa remaja. Pada puncak pertumbuhan, remaja makan lebih sering dan banyak dari biasanya dan kemudian akan mempengaruhi pola makan, terutama dalam hal ini penyerapan zat-zat gizi yang terkandung dalam makanan. ${ }^{3}$ Pola makan yang 
tidak terkontrol dan menjadi suatu kebiasaan pada remaja dapat menyebabkan kelebihan berat badan. ${ }^{13}$

\section{SIMPULAN DAN SARAN}

\section{Simpulan}

Berdasarkan hasil penelitian serta analisa data dapat disimpukan bahwa:

1. Pengetahuan gizi santriwati di Pondok Pesantren Amanatul Ummah Surabaya hampir setengahnya memiliki pengetahuan cukup.

2. Kebiasaan makan santriwati di Pondok Pesantren Amanatul Ummah Surabaya sebagian besar memiliki kebiasaan makan normal

3. Berat badan santriwati di Pondok Pesantren Amanatul Ummah Surabaya, diketahui sebagian besar memiliki berat badan normal.

4. Tidak ada hubungan antara pengetahuan gizi dengan berat badan santriwati di Pondok Pesantren Amanatul Ummah Surabaya.

5. Ada hubungan antara kebiasaan makan dengan berat badan santriwati di Pondok Pesantren Amanatul Ummah Surabaya.

\section{Saran}

Berdasarkan hasil penelitian diperoleh saran sebagai berikut:

1. Bagi siswa

Diharapakan siswi yang memiliki kebiasaan makan berlebih diharapkan dapat memeperbaiki kebiasaan makan dalam kesehariannya dan diimbangi dengan aktivitas fisik yang cukup serta mampu menerapkan pengetahuan gizi yang dimiliki dalam kehidupan sehari-hari

2. Bagi Pondok Pesantren

Diharapkan pihak pondok pesantren untuk mengadakan pengukuran berat badan dan pemeriksaan kesehatan, selain itu memperhatikan jajanan yang dijual di katin agar dapat menjual makanan yang lebih sehat, sertapihak penyelenggara makanan dapat menyusun siklus menu yang sesuai dengan dengan PUGS agar dapat memenuhi kebutuhab santri akan zat gizi

3. Bagi peneliti lain

Diharapkan adanya penelitian dengan menggunakan desain studi yang berbeda, instrument dan pengkuran yang tepat sehingga dapat diperoleh hasil penelitian yang optimal. Selain itu bagi pengukuran SQ-FFQ diharapkan dengan disertai penggunaan food modeling sehingga hasil lebih akurat.

\section{REFERENSI}

1. Khomsan, A. Pangan dan Gizi Untuk Kesehatan. Jakarta: PT Raja Grafindo Persada. 2010.

2. Kemenkes RI. Riset Kesehatan Dasar; RISKESDAS. Jakarta: Balitbang Kemenkes RI. 2013.

3. Proverawati, A. Ilmu Gizi Untuk Keperawatan \& Gizi Kesehatan. Yogyakarta: Nuha Medika. 2011. 
4. Dewi, S.R. Hubungan Antara Pengetahuan Gizi, Sikap Terhadap Gizi dan Pola Konsumsi Siswa Kelas XII Program Keahlian Jasa Boga Di SMK Negeri 6 Yogyakarta. 2013.

5. Dieny, F.F. Permasalah Gizi pada Remaja Putri. Yogyakarta: Graha Ilmu. 2014.

6. Amelia, F. Konsumsi Pangan, Pengetahuan Gizi, Aktivitas Fisik dan Status Gizi pada Remaja di Kota Sungai Penuh Kabupaten Kerinci Propinsi Jambi. 2008.

7. Langgeng, A \& Yance. Hubungan Pengetahuan Gizi dan Sikap Memilih Makanan Jajanan dengan Status Gizi Siswa SMP Negeri 1 Palu. 2015.

8. Wawan. Teori Pengukuran Sikap dan Perilaku Manusia. Yogyakarta: Nuha Medika. 2011.

9. Emalia, O. Promosi Kesehatan Dalam Lingkup Kesehatan Reproduksi. Yogyakarta: Pustaka Cendikia Press. 2008.
10. Notoatmodjo, S. Kesehatan Masyarakat Ilmu \& Seni . Jakarta: Rineka Cipta. 2007.

11. Zuhdy, N. Hubungan Pola Aktivitas Fisik dan Pola Makan dengan Status Gizi pada Pelajar Putri SMA Kelas 1 Denoasar Utara. 2015.

12. Siregar, R. Hubungan Pola Makan dengan Kejadian Overweight pada Mahasiswa di Stikes Medistra Indonesia Tahun 2013. 2013.

13. Sulistyoningsih, H. Gizi Untuk Kesehatan Ibu dan Anak. Jogjakarta: Graha Ilmu. 2011.

14. Almatsier, S. Prinsip Dasar Ilmu Gizi. Jakarta: Gramedia Pustaka Utama. 2009.

15. Balitbang Kemenkes RI. Riset Kesehatan Dasar; RISKESDAS. Jakarta: Balitbang Kemenkes RI. 2013.

16. Proverawati, A. Obesitas dan Gangguan Perilaku Makan Pada Remaja. Yogyakarta: Nuha Medika. 2010. 